University of South Carolina

Scholar Commons

2-21-2012

\title{
A New Approach for the Preparation of Variable Valence Rare Earth Alloys from Nano Rare Earth Oxides at a Low Temperature in Molten Salt
}

Milin Zhang

Yongde Yan

Wei Han

Xing Li

Zhiyao Hou

See next page for additional authors

Follow this and additional works at: https://scholarcommons.sc.edu/emec_facpub

Part of the Applied Mechanics Commons, and the Electro-Mechanical Systems Commons

\section{Publication Info}

Published in RSC Advances, Volume 2, Issue 4, 2012, pages 1585-1591.

CRSC Advances 2012, Royal Society of Chemistry.

This article cannot be redistributed or further made available.

This article was first published by the Royal Society of Chemistry and can be found at http://dx.doi.org/ 10.1039/C1RA00285F

Zhang, M., Yan, Y., Han, W., Li, D., Hou, Z., Tian, Y., Ye, K., Bao, L., Li, X., \& Zhang, Z. (21 February 2012). A New Approach for the Preparation of Variable Valence Rare Earth Alloys from Nano Rare Earth Oxides at a Low Temperature in Molten Salt. RSC Advances, 2(4), 1585 - 1591. http://dx.doi.org/10.1039/

C1RA00285F

This Article is brought to you by the Mechanical Engineering, Department of at Scholar Commons. It has been accepted for inclusion in Faculty Publications by an authorized administrator of Scholar Commons. For more information, please contact digres@mailbox.sc.edu. 


\section{Author(s)}

Milin Zhang, Yongde Yan, Wei Han, Xing Li, Zhiyao Hou, Yang Tian, Ke Ye, Lihong Bao, Xiaodong Li, and Zhijian Zhang 


\title{
RSC Advances
}

\section{A new approach for the preparation of variable valence rare earth alloys from nano rare earth oxides at a low temperature in molten salt $\dagger$}

\author{
Milin Zhang, ${ }^{* a}$ Yongde Yan, ${ }^{* a b}$ Wei Han, ${ }^{a}$ Xing Li, ${ }^{a}$ Zhiyao Hou, ${ }^{a}$ Yang Tian, ${ }^{a}$ Ke Ye, ${ }^{a}$ Lihong Bao,${ }^{c}$ Xiaodong \\ $\mathrm{Li}^{c}$ and Zhijian Zhang ${ }^{b}$
}

Received 8th June 2011, Accepted 7th November 2011

DOI: 10.1039/c1ra00285f

The solubility of $\mathrm{RE}_{2} \mathrm{O}_{3}(\mathrm{RE}=\mathrm{Eu}, \mathrm{Sm}$, and $\mathrm{Yb})$ with variable valence in molten salts is extremely low. It is impossible to directly obtain variable valence metals or alloys from $\mathrm{RE}_{2} \mathrm{O}_{3}$ using electrolysis in molten salts. We describe a new approach for the preparation of variable valence rare earth alloys from nano rare earth oxide. The excellent dispersion of nano- $\mathrm{Eu}_{2} \mathrm{O}_{3}$ in $\mathrm{LiCl}-\mathrm{KCl}$ melts was clearly observed using a luminescent feature of $\mathrm{Eu}^{3+}$ as a probe. The ratio of solubility of nano- $\mathrm{Sm}_{2} \mathrm{O}_{3} /$ common $\mathrm{Sm}_{2} \mathrm{O}_{3}$ is 16.98. Electrochemical behavior of $\mathrm{RE}_{2} \mathrm{O}_{3}$ on a molybdenum and $\mathrm{Al}$ electrode in $\mathrm{LiCl}-\mathrm{KCl}$ melts containing $\mathrm{AlCl}_{3}$ at $480{ }^{\circ} \mathrm{C}$ was investigated by different electrochemical techniques, such as cyclic voltammetry (CV), square wave voltammetry, and chronopotentiometry. Prior to the reduction peak of $\mathrm{Al}$, the reduction peaks of $\mathrm{Sm}(\mathrm{III}) / \mathrm{Sm}(\mathrm{II}), \mathrm{Yb}(\mathrm{III}) / \mathrm{Yb}(\mathrm{II})$, and $\mathrm{Eu}(\mathrm{III}) / \mathrm{Eu}(\mathrm{II})$ were observed at about $-0.85,-0.45$, and $0.39 \mathrm{~V}$ in square wave voltammetry, respectively. The underpotential deposition of RE on pre-deposited aluminum leads to the formation of Al-RE alloy. The structure, morphology, and energy dispersion analysis of the deposit obtained by potentiostatic electrolysis are analyzed. $\mathrm{Al}_{2} \mathrm{Sm}$ and $\mathrm{Al}_{3} \mathrm{Sm}$ alloys were successfully obtained from nano- $\mathrm{Sm}_{2} \mathrm{O}_{3}$.

\section{Introduction}

It has been long thought that rare earth $(\mathrm{RE}=\mathrm{Eu}, \mathrm{Sm}$, and $\mathrm{Yb})$ metals with variable valencies can not be obtained via reduction of their halides using $\mathrm{Ca}$ or $\mathrm{Li}$ as a reducer, because these $\mathrm{RE}$ metals can form stable bivalent halides. In principle, since the reduction potential of $\mathrm{RE}(\mathrm{II})$ to $\mathrm{RE}(0)$ is even more negative than the solvent in the chloride system, it is impossible to prepare variable valence RE metals directly by electrolysis from molten salt chlorides. The only technique for making variable valence $\mathrm{RE}$ metals is through reduction by lanthanum, cerium or their mixture with low vapor tension, and distillation at high temperature in a vacuum. However, this methodology has many drawbacks, such as low throughput, a complex and discontinuous production processes, and high energy consumption. In such a process, lanthanum and cerium prepared by electrolysis are essential reduction materials, but incur a high cost. A better approach to produce these variable valence RE metals is alloying directly with other metals. ${ }^{1-7}$

${ }^{a}$ Key Laboratory of Superlight Materials and Surface Technology, Ministry of Education, College of Materials Science and Chemical Engineering, Harbin Engineering University, Harbin, 150001, China. E-mail: zhangmilin@hrbeu.edu.cn; y5d2006@hrbeu.edu.cn;

Fax: +86 (0) 451 82533026; Tel: +86 (0) 45182533026

${ }^{b}$ College of Nuclear Science and Technology, Harbin Engineering University, Harbin, 150001, China

${ }^{c}$ Department of Mechanical Engineering, University of South Carolina, 300 Main Street, Columbia, South Carolina, 29208, USA

$\dagger$ Electronic Supplementary Information (ESI) available. See DOI: 10.1039/c1ra00285f/
In the past decades, the raw materials for the preparation of variable valence RE alloys are RE chlorides and fluorides, obtained via the chlorination and fluorination of RE oxides. However, toxic and corrosive $\mathrm{HCl}$ and $\mathrm{HF}$ have to be bubbled into the melts to avoid the formation of $\mathrm{RE}_{2} \mathrm{O}_{3}$ precipitates during the electrolysis process, because $\mathrm{RE}(\mathrm{III})$ is very sensitive to $\mathrm{O}^{2-}$ ions. In order to overcome the drawbacks of the route using chlorides and fluorides as precursors, some researchers have achieved metals, nonmetals, or alloys from their respective oxides via electrochemical reduction in molten salts. Chen and Fray ${ }^{8}$ reported the direct electro-deoxidation of titanium dioxide to titanium in calcium chloride. $\mathrm{Chen}^{9}$ further investigated the electrochemical metallization of solid terbium oxide to terbium metal under $\mathrm{Ca}$ deposition in molten $\mathrm{CaCl}_{2}$. The electroreduction of solid titanium and terbium oxide to their respective metals can only proceed under the conditions for $\mathrm{Ca}$ deposition and predominantly electro-deoxidize with little contribution of $\mathrm{Ca}$ reduction. Nohira et al. ${ }^{10}$ succeeded in removing oxygen from the surfaces of solid $\mathrm{SiO}_{2}$ plates in a molten $\mathrm{CaCl}_{2}$ electrolyte at $850{ }^{\circ} \mathrm{C}$. Chen et al. ${ }^{11}$ developed an electrochemical preparation of nonmetallic silicon and its alloys from solid oxides in the same melt. However, the electrochemical preparation of variable valence RE metals or alloys from solid oxides in molten salts has hitherto not been reported. Here we present a new approach for making $\mathrm{RE}$ alloys from nanosized $\mathrm{RE}_{2} \mathrm{O}_{3}$ by taking advantage of nano effects for the first time. This new technique overcomes the limitation of low $\mathrm{RE}_{2} \mathrm{O}_{3}$ solubility in molten salts, and opens up unprecedented opportunities for making RE and other alloys 
which have been thought impossible before. Compared with direct electro-deoxidation (FFC Cambridge process), this technique offers an alternative route to fabricate alloys from oxide using the reduction of metallic ions dissolved in molten salts.

\section{Experimental}

\subsection{Nanoparticle synthesis}

Nano particles of $\mathrm{Eu}_{2} \mathrm{O}_{3}, \mathrm{Sm}_{2} \mathrm{O}_{3}, \mathrm{Yb}_{2} \mathrm{O}_{3}$ and $\mathrm{Y}_{2} \mathrm{O}_{3}: \mathrm{Eu}^{3+}$ were all prepared by sol-gel process. The doping concentration of $\mathrm{Eu}^{3+}$ is $5 \mathrm{~mol} \%$ that of $\mathrm{Y}^{3+}$ in $\mathrm{Y}_{2} \mathrm{O}_{3}$ host, which has been optimized previously. ${ }^{12} \mathrm{Eu}_{2} \mathrm{O}_{3}, \mathrm{Sm}_{2} \mathrm{O}_{3}, \mathrm{Yb}_{2} \mathrm{O}_{3}$, and stoichiometric amounts of $\mathrm{Y}_{2} \mathrm{O}_{3}$ and $\mathrm{Eu}_{2} \mathrm{O}_{3}$ (all with purity of $99.999 \%$, Science and Technology Parent Company of Changchun Institute of Applied Chemistry, China) were dissolved in $\mathrm{HNO}_{3}$ (A. R.) and then mixed with a water-ethanol $(\mathrm{v} / \mathrm{v}=1: 7)$ solution containing citric acid (A. R.) as a chelating agent for the metal ions. The molar ratio of metal ions to citric acid was $1: 2$. Polyethylene glycol (PEG, molecular weight $=10$ 000, A. R.) was added to adjust the viscoelasticity of the solution (a final concentration of PEG is $0.08 \mathrm{~g} \mathrm{~mL}^{-1}$ in the water-ethanol solution). The resultant mixtures were stirred for $1 \mathrm{~h}$ to obtain a homogeneous hybrid sol and heated at $75{ }^{\circ} \mathrm{C}$ in a water bath until homogeneous gels formed. After being dried in an oven at $110{ }^{\circ} \mathrm{C}$ for $10 \mathrm{~h}$, the gels were ground and prefired at $500{ }^{\circ} \mathrm{C}$ for $3 \mathrm{~h}$ in air. Finally the samples were fully ground and fired to $700{ }^{\circ} \mathrm{C}$ for $3 \mathrm{~h}$.

\subsection{Purification of the melts and solubility measurement of $\mathrm{RE}_{2} \mathrm{O}_{3}$}

The mixture of $\mathrm{LiCl}-\mathrm{KCl}$ (50:50 wt $\%$, analytical grade) was first dried under vacuum for more than $72 \mathrm{~h}$ at $473 \mathrm{~K}$ to remove excess water. Metal ion impurities in the melts were removed by pre-electrolysis at $-2.0 \mathrm{~V}$ (vs. $\mathrm{Ag} / \mathrm{AgCl}$ ) for 4 h. ${ }^{13,14}$ Aluminum and samarium, ytterbium and europium ions were introduced into the bath in the form of $\mathrm{AlCl}_{3}, \mathrm{Sm}_{2} \mathrm{O}_{3}, \mathrm{Yb}_{2} \mathrm{O}_{3}$, and $\mathrm{Eu}_{2} \mathrm{O}_{3}$ powders. To determine the solubility of $\mathrm{RE}_{2} \mathrm{O}_{3}(\mathrm{wt} \%)$ in the $\mathrm{LiCl}-\mathrm{KCl}$ melts at $480{ }^{\circ} \mathrm{C}$, the nanosized and common particles were added into the $\mathrm{LiCl}-\mathrm{KCl}$ melts and held for $3 \mathrm{~h}$ at $480{ }^{\circ} \mathrm{C}$, and then the samples were taken from the clear supernatant fluid in the molten salt mixtures. After the clear supernatant fluid samples were solidified, each sample was dissolved in distilled water for analysis. The solution was diluted and analyzed using an inductively coupled plasma atomic emission spectrometer (ICP-AES, IRIS Intrepid II XSP, Thermo Elemental). The contents of $\mathrm{K}^{+}, \mathrm{Li}^{+}$, and $\mathrm{RE}^{3+}$ measured by ICP were converted to the masses of $\mathrm{KCl}, \mathrm{LiCl}$, and $\mathrm{RE}_{2} \mathrm{O}_{3}$, and then the solubility of $\mathrm{RE}_{2} \mathrm{O}_{3}$ in $\mathrm{LiCl}-\mathrm{KCl}$ melts was calculated.

\subsection{Electrochemical apparatus and electrodes}

All electrochemical measurements were carried out using an electrochemical workstation (Im6eX, Zahner Co., Ltd.) with THALES 3.08 software package. A silver wire with a diameter of $1 \mathrm{~mm}$, which was dipped into a solution of $\mathrm{AgCl}(1 \mathrm{wt} \%)$ in $\mathrm{LiCl}-\mathrm{KCl}$ melts contained in a Pyrex tube was used as a reference electrode. A spectrally pure graphite rod with a diameter of $6 \mathrm{~mm}$ served as the counter electrode. The working electrodes were molybdenum wires (diameter $1 \mathrm{~mm}, 99.99 \%$ purity), which were polished using $\mathrm{SiC}$ paper to remove the surface oxides, then cleaned ultrasonically with ethanol prior to use. The active electrode surface area was determined after each experiment by measuring the immersion depth of the electrode in the molten salts.

\subsection{Preparation and characterization of Al-RE alloys}

The Al-RE alloys were prepared by potentiostatic electrolysis under different conditions. After electrolysis, all samples were washed with hexane (99.8\% purity) in an ultrasonic bath to remove salts and then stored in a glove box for analysis. These deposits were analyzed by X-ray diffraction (XRD, X' Pert Pro; Philips Co., Ltd.) using $\mathrm{Cu}-\mathrm{K} \alpha$ radiation at $40 \mathrm{kV}$ and $40 \mathrm{~mA}$. The microstructure of the Al-RE alloys was measured by scanning electron microscopy (SEM) and energy dispersive spectrometry (EDS) mapping analysis (JSM-6480A; JEOL Co., Ltd.).

\section{Results and discussion}

\subsection{Characterization of nanosized $\mathrm{RE}_{2} \mathrm{O}_{3}$}

In the first step, we prepared nanosized $\mathrm{Eu}_{2} \mathrm{O}_{3}, \mathrm{Sm}_{2} \mathrm{O}_{3}$ and $\mathrm{Yb}_{2} \mathrm{O}_{3}$ particles by a sol-gel process. Fig. 1 shows the XRD spectra of the as-prepared $\mathrm{Eu}_{2} \mathrm{O}_{3}, \mathrm{Sm}_{2} \mathrm{O}_{3}$ and $\mathrm{Yb}_{2} \mathrm{O}_{3}$ samples together with the JCPDS cards for $\mathrm{Eu}_{2} \mathrm{O}_{3}$ (No. 34-0392), $\mathrm{Sm}_{2} \mathrm{O}_{3}$ (No. 15-0813) and $\mathrm{Yb}_{2} \mathrm{O}_{3}$ (No. 65-3173), respectively. All the diffraction peaks of these samples can be readily indexed to their corresponding standard patterns. No diffraction peaks of any impurity were observed, indicating high purity of these final products. These results suggest that the precursor samples were crystallized into $\mathrm{Eu}_{2} \mathrm{O}_{3}, \mathrm{Sm}_{2} \mathrm{O}_{3}$ and $\mathrm{Yb}_{2} \mathrm{O}_{3}$ at the heating temperature of $700{ }^{\circ} \mathrm{C}$.

Fig. 2a, d and g illustrate a representative overview of the morphologies of the $\mathrm{Eu}_{2} \mathrm{O}_{3}, \mathrm{Sm}_{2} \mathrm{O}_{3}$ and $\mathrm{Yb}_{2} \mathrm{O}_{3}$ samples, respectively. The obtained samples are composed of aggregated spherical nanoparticles with a size range from $10 \mathrm{~nm}$ to $50 \mathrm{~nm}$. The HRTEM images and corresponding FFT diffraction patterns (Fig. 2b and c, 2e and f, 2h and i) reveal that individual nanoparticles of $\mathrm{Eu}_{2} \mathrm{O}_{3}, \mathrm{Sm}_{2} \mathrm{O}_{3}$, and $\mathrm{Yb}_{2} \mathrm{O}_{3}$ are single crystals. No defects were observed in the nanoparticles.

The bulk density of the nano-particles $\left(\mathrm{RE}_{2} \mathrm{O}_{3}\right)$ is readily compared with normal particles, as shown in Fig. 3a-c. The bulk density ratios of nano to normal for $\mathrm{Eu}_{2} \mathrm{O}_{3}, \mathrm{Sm}_{2} \mathrm{O}_{3}, \mathrm{Yb}_{2} \mathrm{O}_{3}$ are

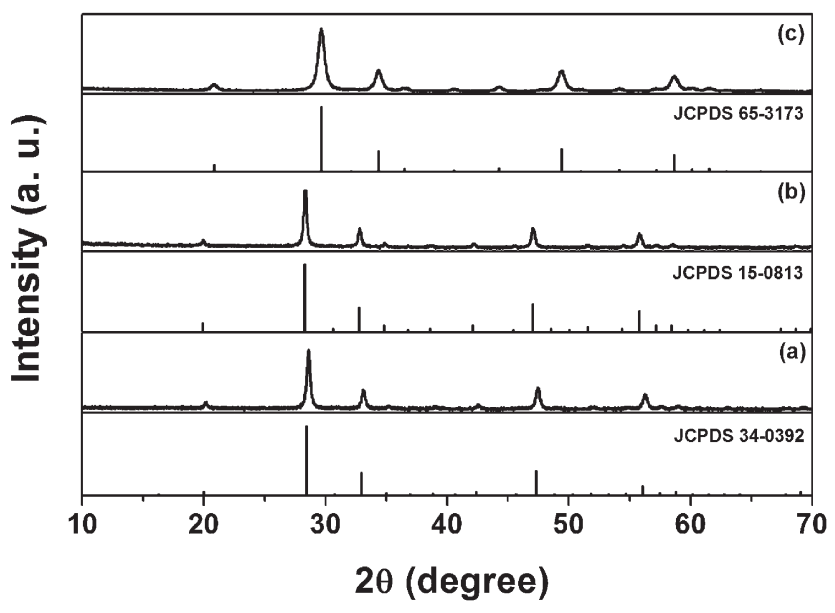

Fig. 1 X-ray diffraction spectra for $\mathrm{Eu}_{2} \mathrm{O}_{3}$ (a), $\mathrm{Sm}_{2} \mathrm{O}_{3}$ (b) and $\mathrm{Yb}_{2} \mathrm{O}_{3}$ (c) samples after annealing at $700{ }^{\circ} \mathrm{C}$ for $3 \mathrm{~h}$ in air, the JCPDS card 34-0392 for $\mathrm{Eu}_{2} \mathrm{O}_{3}, 15-0813$ for $\mathrm{Sm}_{2} \mathrm{O}_{3}$ and 65-3173 for $\mathrm{Yb}_{2} \mathrm{O}_{3}$. 


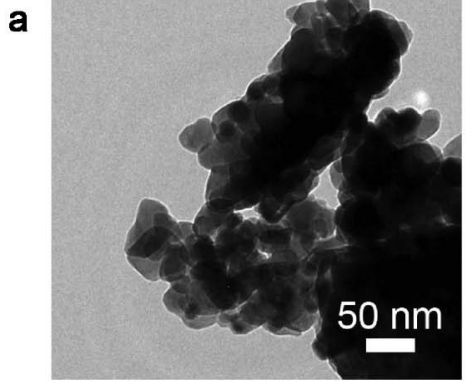

d

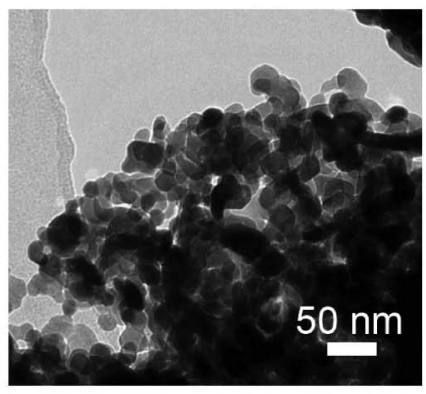

g

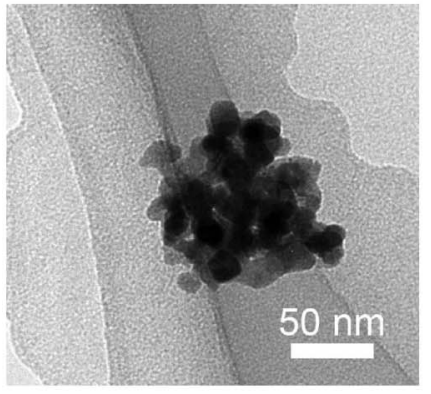

b

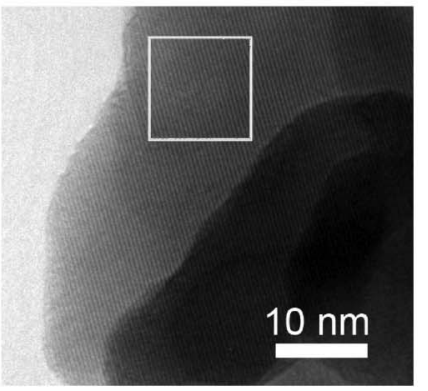

e

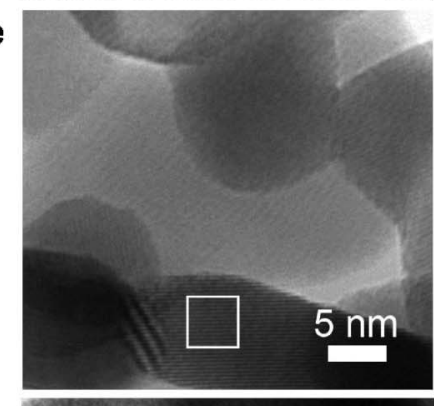

h

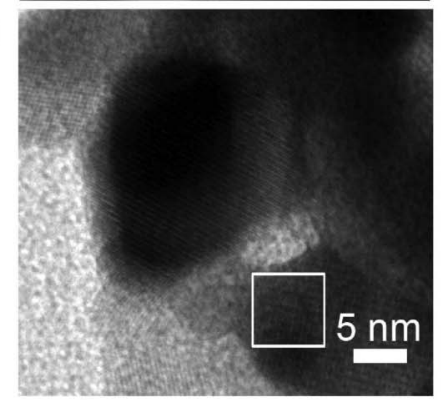

c

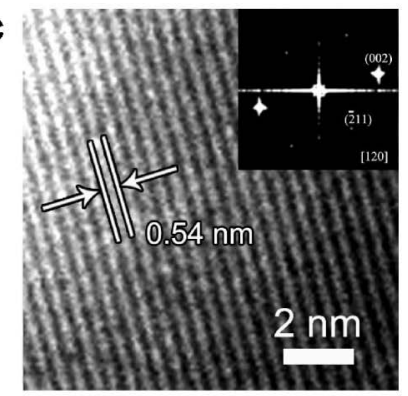

f
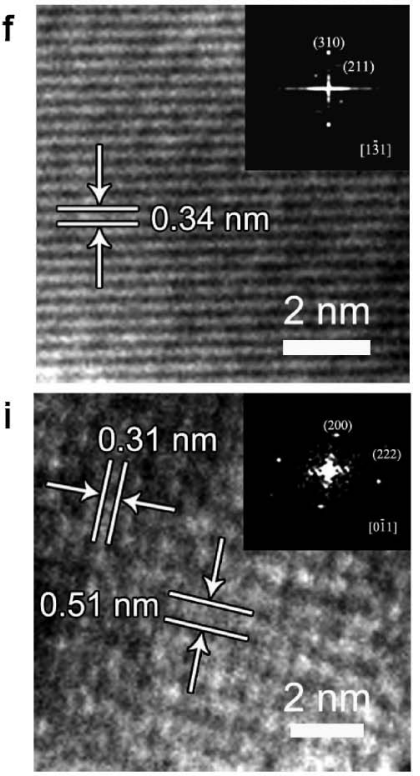

Fig. 2 TEM images of $\mathrm{Eu}_{2} \mathrm{O}_{3}$ (a) with its $\operatorname{HRTEM}(\mathrm{b}, \mathrm{c}), \mathrm{Sm}_{2} \mathrm{O}_{3}$ (d) with its HRTEM (e, f) and $\mathrm{Yb}_{2} \mathrm{O}_{3}$ (g) with its HRTEM (h, i).

$0.75,0.77$ and 0.85 , respectively. Compared with common materials, nano-particles in nano-materials interleave each other and form a porous network structure, resulting in greater porosity. Therefore, the bulk density of the aggregated nanosized $\mathrm{Sm}_{2} \mathrm{O}_{3}$ is lower compared to common materials. The solubility values of normal and nano $\mathrm{Sm}_{2} \mathrm{O}_{3}$, measured in the $\mathrm{LiCl}-\mathrm{KCl}$ melts at $480{ }^{\circ} \mathrm{C}$, were 0.007981 and $0.1355 \mathrm{wt} \%$, respectively, as shown in Fig. 3d-f. The ratios of solubility of nano $\mathrm{RE}_{2} \mathrm{O}_{3}(\mathrm{RE}=$ $\mathrm{Eu}, \mathrm{Sm}, \mathrm{Yb})$ /common $\mathrm{RE}_{2} \mathrm{O}_{3}(\mathrm{wt} \%$ ) are 13.81, 16.98, and 17.29, respectively. The large increase of solubility for nano-materials can be ascribed to the following reasons. According to the view presented by $\mathrm{Ma},{ }^{15}$ the decrease in particle size from normal $\mathrm{RE}_{2} \mathrm{O}_{3}$ to the nano size leads to a larger dangling-bond density. The existence of a mass of dangling bonds will principally generate two results: On one hand, the dangling bonds increase the surface energy, which consequently decreases the critical temperatures of thermodynamic processes like the melting point, ${ }^{16}$ crystallization temperature, ${ }^{17}$ sintering temperature. ${ }^{18}$ On the other hand, dangling bonds have a tendency of binding to other atoms. Accordingly, they become the active centers for adatom adsorption and interaction, making some thermodynamic processes and chemical reactions easier. ${ }^{15}$ The nanoparticles have smaller dimensions and larger specific surface areas, which facilitate greater contact of $\mathrm{RE}_{2} \mathrm{O}_{3}$ with $\mathrm{Cl}^{-}$. The nanoparticles, therefore, possess more active atoms than normal ones, which are highly active to absorb large numbers of $\mathrm{Cl}^{-}$. These factors facilitate the diffusion of $\mathrm{RE}_{2} \mathrm{O}_{3}$ nanoparticles into the melts.
The practical states of dispersion of common and nanosized $\mathrm{RE}_{2} \mathrm{O}_{3}$ are plotted in Fig. 3g-i. To further illuminate the dispersion of the $\mathrm{Eu}_{2} \mathrm{O}_{3}$ sample, we also added nanosized $\mathrm{Y}_{2} \mathrm{O}_{3}: \mathrm{Eu}^{3+}$ phosphors (prepared by sol-gel process) to the $\mathrm{LiCl}-$ $\mathrm{KCl}$ melt system due to their luminescent feature. As the main and unsurpassed red emitting materials in fluorescent lamps and flat panel devices, $\mathrm{Y}_{2} \mathrm{O}_{3}: \mathrm{Eu}^{3+}$ phosphors inevitably gather more attention because of their good luminescent characteristics, acceptable atmospheric stability, reduced degradation under applied voltages, and the lack of hazardous constituents as opposed to sulfide phosphors. ${ }^{19,20}$ The $\mathrm{Eu}^{3+}$ ion is an important $\mathrm{RE}$ ion that acts as an activator, which mainly shows emission due to transitions of ${ }^{5} \mathrm{D}_{0}-{ }^{7} \mathrm{~F}_{\mathrm{J}}(J=4,3,2,1,0)$ in the red regions. ${ }^{21}$ The $\mathrm{LiCl}-\mathrm{KCl}-\mathrm{Y}_{2} \mathrm{O}_{3}: \mathrm{Eu}^{3+}$ system clearly exhibits a red emission upon $254 \mathrm{~nm}$ excitation under a UV lamp (see Fig. 3j). Under short wavelength UV irradiation, $\mathrm{Y}_{2} \mathrm{O}_{3}: \mathrm{Eu}^{3+}$ phosphors exhibit the characteristic red emission of $\mathrm{Eu}^{3+}$, dominated by the hypersensitive ${ }^{5} \mathrm{D}_{0}-{ }^{7} \mathrm{~F}_{2}$ transition of $\mathrm{Eu}^{3+}$ at about $612 \mathrm{~nm} .^{20}$ The red emission of the melts system in the quartz tube, with the addition of $\mathrm{Y}_{2} \mathrm{O}_{3}: \mathrm{Eu}^{3+}$, indicates that $\mathrm{Y}_{2} \mathrm{O}_{3}: \mathrm{Eu}^{3+}$ phosphors disperse in the system homogeneously. Different from nano- $\mathrm{RE}_{2} \mathrm{O}_{3}$ uniformly dispersing in the melts, common $\mathrm{RE}_{2} \mathrm{O}_{3}$ sinks to the bottom of the quartz tube (Fig. $3 \mathrm{k}$ ).

In the vicinity of $\mathrm{RE}_{2} \mathrm{O}_{3}$ atoms, $\mathrm{RE}^{3+}$ ions are in higher concentration than in the bulk solution. $\mathrm{RE}_{2} \mathrm{O}_{3}$ atoms and $\mathrm{RE}^{3+}$ ions form a positively charged complex, of which there is abundance in the melts. Electrostatic repulsion between these 


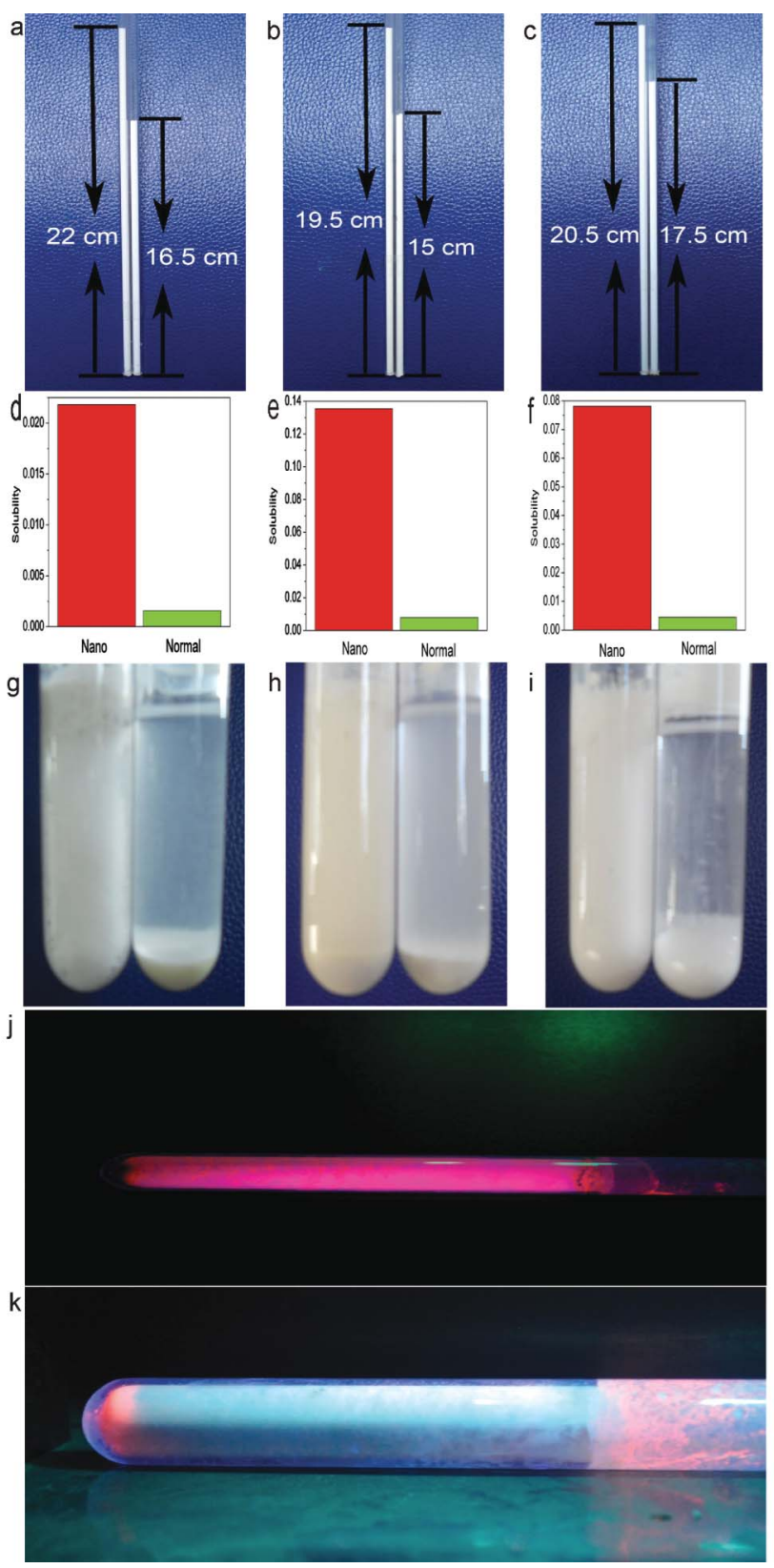

Fig. 3 bulk density (a-c); solubility (d-f); dispersion of $\mathrm{Eu}_{2} \mathrm{O}_{3}, \mathrm{Sm}_{2} \mathrm{O}_{3}$, $\mathrm{Yb}_{2} \mathrm{O}_{3}$ (left: nano, right: common $\mathrm{RE}_{2} \mathrm{O}_{3}$ ) (g-i); and luminescent photograph of nano (j) and normal (k) $\mathrm{Y}_{2} \mathrm{O}_{3}: \mathrm{Eu}^{3+}$ in the LiCl- $\mathrm{KCl}$ melts.

complexes promotes suspension, which could explain the even dispersion of particles in melts. This could explain why nano$\mathrm{RE}_{2} \mathrm{O}_{3}$ particles can disperse well in melts. Small size, high solubility and even dispersion of nano-particles are prerequisites for electrolyzing $\mathrm{RE}$ alloys from $\mathrm{RE}_{2} \mathrm{O}_{3}$ in melts.

\subsection{Electrochemical behavior of nano- $\mathrm{RE}_{2} \mathrm{O}_{3}$ on $\mathrm{Mo}$ and $\mathrm{Al}$ electrodes}

The element Al was selected as an alloying element in the variable valence $\mathrm{RE}$ alloys due to its excellent mechanical properties. The electrochemical behavior of $\mathrm{LiCl}-\mathrm{KCl}$ containing $\mathrm{AlCl}_{3}$ and $\mathrm{RE}_{2} \mathrm{O}_{3}(\mathrm{Sm}, \mathrm{Yb}, \mathrm{Eu})$ on a molybdenum electrode was studied. Fig. 4 shows the representative CVs obtained on molybdenum electrodes $\left(S=0.322 \mathrm{~cm}^{2}\right)$ before and after the addition of $2 \mathrm{wt} \% \mathrm{AlCl}_{3}$ and $1 \mathrm{wt} \%$ nano- $\mathrm{Sm}_{2} \mathrm{O}_{3}, 1 \mathrm{wt} \%$ nano$\mathrm{Yb}_{2} \mathrm{O}_{3}$, and $1 \mathrm{wt} . \%$ nano- $\mathrm{Eu}_{2} \mathrm{O}_{3}$ in $\mathrm{LiCl}-\mathrm{KCl}$ melts at $480{ }^{\circ} \mathrm{C}$. The dotted curve represents the voltammogram before the addition of $\mathrm{AlCl}_{3}$ and $\mathrm{RE}_{2} \mathrm{O}_{3}$. Only one couple of the cathodic/ anodic signals $\mathrm{D} / \mathrm{D}^{\prime}$ is observed, corresponding to the deposition and dissolution of liquid $\mathrm{Li}$, since no alloys or intermetallic compounds exist in the Mo-Li binary system at $480{ }^{\circ} \mathrm{C}$. The solid curves show the voltammograms measured after the addition of $\mathrm{AlCl}_{3}$ and $\mathrm{RE}_{2} \mathrm{O}_{3}$. Since all three kinds of melts contain $\mathrm{AlCl}_{3}$ and their deposition potentials are almost the same, cathodic peak $\mathrm{A}$ is observed from approximate $-1.00 \mathrm{~V}$ (vs $\mathrm{Ag} / \mathrm{AgCl}$ ) which corresponds to the reduction of $\mathrm{Al}$ (III) in $\mathrm{LiCl}-\mathrm{KCl}-\mathrm{AlCl}_{3}-\mathrm{RE}_{2} \mathrm{O}_{3}$ melts. An anodic current background or wave on the neck of anodic peak $\mathrm{A}^{\prime}$ (the oxidation of deposited metal Al) is likely to be associated with the formation of Al-Mo alloy in the positive-going scan (Fig. S1, ESI $\dagger$ ). It is not feasible to study the redox $\mathrm{RE}(\mathrm{II}) / \mathrm{RE}(0)$ system because $\mathrm{RE}(\mathrm{II})$ is reduced to $\mathrm{RE}(0)$ at a high negative value close to that of lithium reduction, which agrees with data in the literature. ${ }^{22-24}$ However, because nano $\mathrm{RE}_{2} \mathrm{O}_{3}$ can be well dispersed in molten $\mathrm{LiCl}-\mathrm{KCl}$ salt at low temperature, the underpotential deposition of RE on pre-deposited aluminum leads to the formation of Al$\mathrm{RE}(\mathrm{RE}=\mathrm{Sm}, \mathrm{Yb}$, and Eu) alloys, marked by cathodic current peaks $B_{1}, B_{2}$, and $B_{3}$, respectively. The peak of alloy formation was observed in melts containing nano $\mathrm{RE}_{2} \mathrm{O}_{3}$. Nano effects, responsible for this behavior, give rise to high solubility and even dispersion in melts, and subsequently result in the deposition of $\mathrm{RE}$ on $\mathrm{Al}$ and formation of $\mathrm{Al}-\mathrm{RE}$ alloys. After peaks $\mathrm{B}_{2}$ and $\mathrm{B}_{3}$, a current wave $\mathrm{C}$ is observed, which is associated with the underpotential deposition of $\mathrm{Li}(\mathrm{I})$ on pre-deposited $\mathrm{Al}$ forming Al-Li alloys. On the anodic sweep, $\mathrm{A}^{\prime}, \mathrm{B}^{\prime}$, and $\mathrm{C}^{\prime}$ are related to the oxidation of metallic $\mathrm{Al}, \mathrm{Al}-\mathrm{RE}$ and $\mathrm{Al}-\mathrm{Li}$ alloys. From the inset graph in Fig. 4(a) and (b), $\mathrm{B}_{1}{ }^{\prime}$ and $\mathrm{B}_{2}{ }^{\prime}$ are split into two oxidation peaks $\mathrm{B}_{1}{ }^{\prime \prime}$ and $\mathrm{B}_{1}{ }^{\prime \prime \prime}$, and $\mathrm{B}_{2}{ }^{\prime \prime}$ and $\mathrm{B}_{2}{ }^{\prime \prime}$, respectively. According to the phase diagram of $\mathrm{Al}-\mathrm{Sm}$ and $\mathrm{Al}-\mathrm{Yb}$ system, ${ }^{25}$ the oxidation peaks $\mathrm{B}_{n}{ }^{\prime \prime}$ and $\mathrm{B}_{n}{ }^{\prime \prime \prime}$ ( $n=1$ and 2 ) correspond to two intermetallic compounds of $\mathrm{Al}-\mathrm{Sm}$ and $\mathrm{Al}-\mathrm{Yb}$ alloys, respectively. The redox peaks of $\mathrm{REs}(\mathrm{III})$ to $\mathrm{REs}(\mathrm{II})$, which should have occurred prior to Al signals, are not clearly observed. This is probably because the concentration of $\mathrm{RE}_{2} \mathrm{O}_{3}$ is relatively low and the redox peaks are not easily found in comparison with the larger-scaled peak A. Another possible explanation is that the $\mathrm{CV}$ experiments did not cover a wider potential range. These points were proved in square wave voltammetry and Fig. S1, ESI. $\uparrow$ The reduction signals of REs(III) to REs(II) with the same concentration are detected in square wave voltammetry (see Fig. 5), which is a more sensitive method than cyclic voltammetry. Prior to the reduction peak of $\mathrm{Al}$, the reduction peaks of $\mathrm{Sm}(\mathrm{III}) / \mathrm{Sm}(\mathrm{II}), \mathrm{Yb}(\mathrm{III}) / \mathrm{Yb}(\mathrm{II})$, and $\mathrm{Eu}(\mathrm{III}) /$ $\mathrm{Eu}(\mathrm{II})$ were observed at about $-0.85,-0.45$, and $0.39 \mathrm{~V}$, respectively. These values are in agreement with the data reported in literature, ${ }^{4,72}$ when temperature and melt system differences are taken into account. The formation signal of AlMo is also observed between the reduction peaks of $\mathrm{Al}$ and $\mathrm{RE}(\mathrm{III})$ to $\mathrm{RE}$ (II) (RE = Eu and $\mathrm{Yb}$ ). We do not observe the peak (or shoulder) corresponding to Al-Mo formation in $\mathrm{LiCl}-\mathrm{KCl}-$ $\mathrm{AlCl}_{3}-\mathrm{Sm}_{2} \mathrm{O}_{3}$ melts. The signal is probably hidden by a largerscale reduction current of $\mathrm{Sm}$ (III) to $\mathrm{Sm}(\mathrm{II})$ due to the slight 

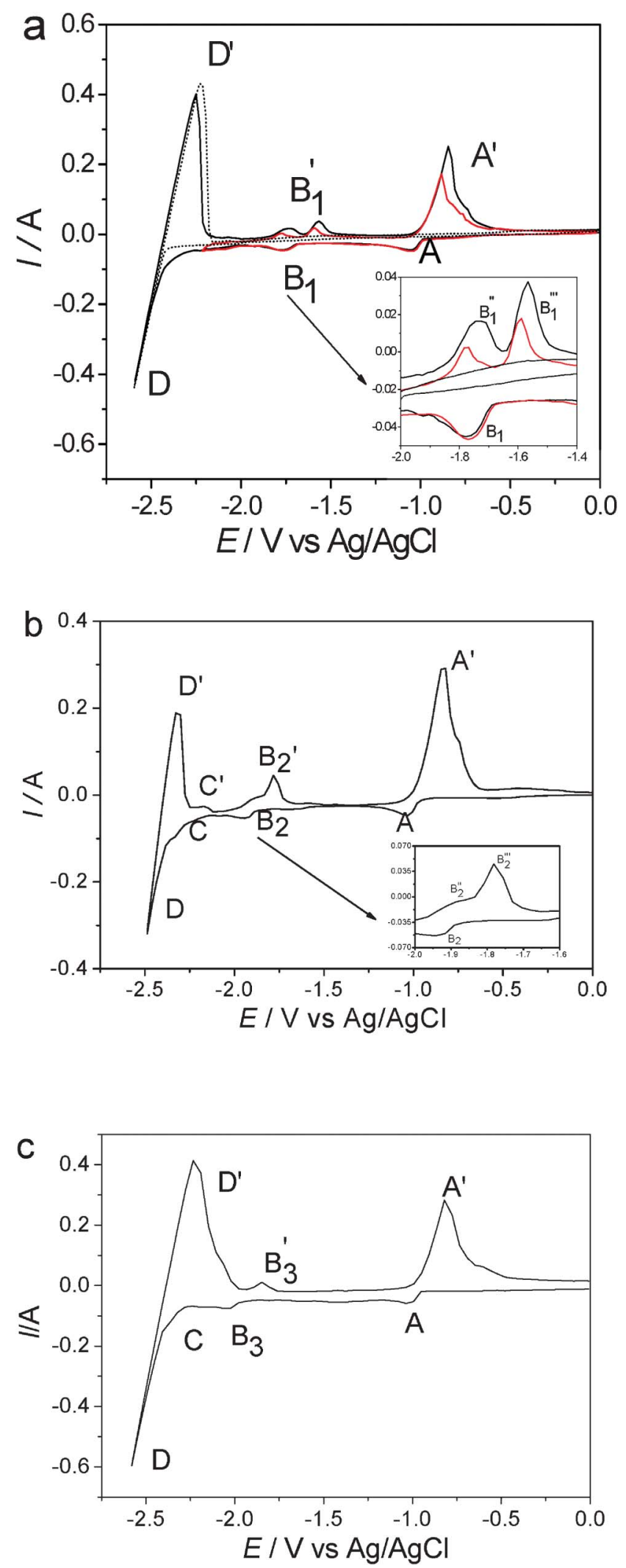

Fig. $4 \mathrm{CVs}$ of the $\mathrm{LiCl}-\mathrm{KCl}$ melts before (dotted line) and after (solid line) the addition of $2 \mathrm{wt} \% \mathrm{AlCl}_{3}$ and $1 \mathrm{wt} \%$ (a) nano- $\mathrm{Sm}_{2} \mathrm{O}_{3}$ (b) nano$\mathrm{Yb}_{2} \mathrm{O}_{3}$ (c) nano- $\mathrm{Eu}_{2} \mathrm{O}_{3}$ on molybdenum electrodes $\left(S=0.322 \mathrm{~cm}^{2}\right)$ at different cathodic limits at $480{ }^{\circ} \mathrm{C}$. Scan rate: $0.1 \mathrm{~V} \mathrm{~s}^{-1}$.
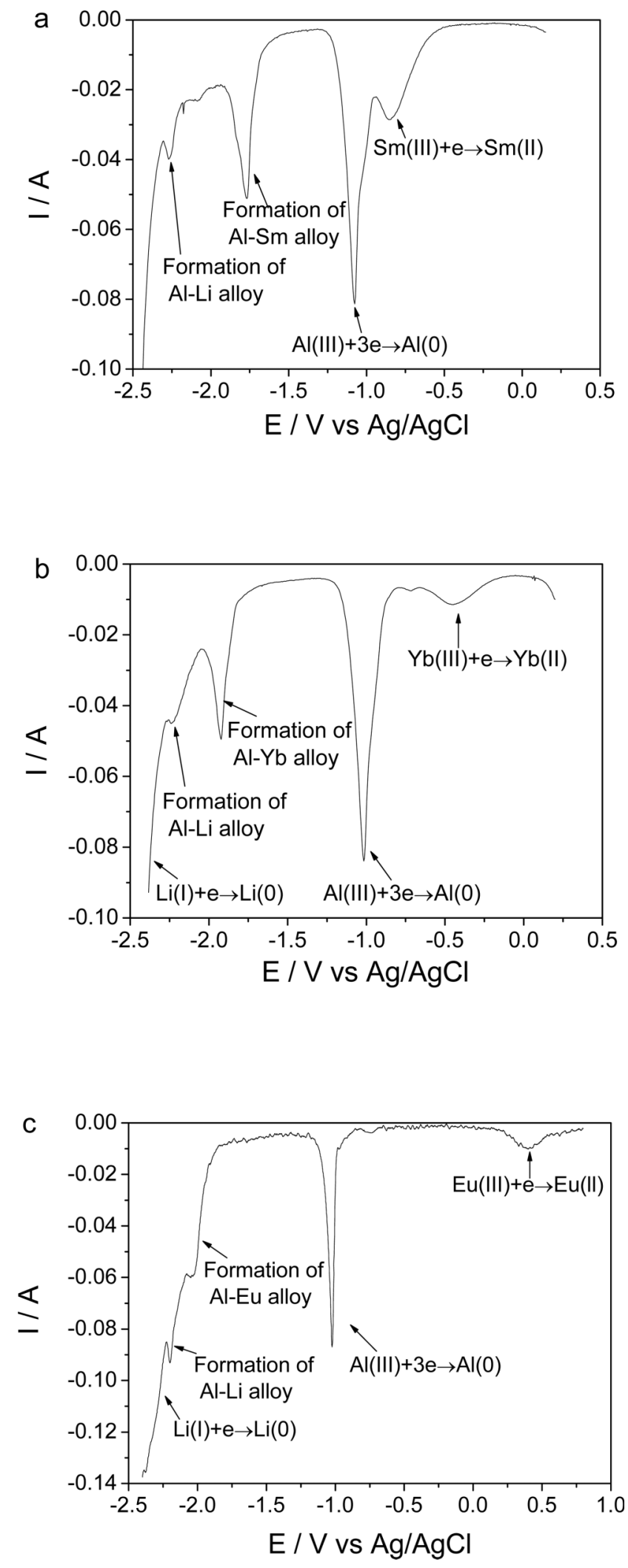

Fig. 5 Square wave voltammograms of the $\mathrm{LiCl}-\mathrm{KCl}-\mathrm{AlCl}_{3}(2 \mathrm{wt} \%)$ melts after the addition of $1 \mathrm{wt} \%$ nano-materials (a) $\mathrm{Sm}_{2} \mathrm{O}_{3}$ (b) $\mathrm{Yb}_{2} \mathrm{O}_{3}$ (c) $\mathrm{Eu}_{2} \mathrm{O}_{3}$ on molybdenum electrodes $\left(S=0.322 \mathrm{~cm}^{2}\right)$ at $480{ }^{\circ} \mathrm{C} . F=20 \mathrm{~Hz}$. 
difference of their formation potential. Two additional cathodic peaks after the reduction peak of $\mathrm{Al}$ correspond to the underpotential deposition of $\mathrm{RE}(\mathrm{Sm}, \mathrm{Yb}$, and $\mathrm{Eu}$ ) and $\mathrm{Li}$ on pre-deposited Al forming Al-RE and Al-Li alloys, respectively.

In the previous section, the electro-deposition of Al-RE alloys from nano- $\mathrm{RE}_{2} \mathrm{O}_{3}$ was studied on an inert electrode. The electrochemical behavior of nano- $\mathrm{RE}_{2} \mathrm{O}_{3}$ was also investigated on an active $\mathrm{Al}$ electrode using $\mathrm{CVs}$ and open-circuit chronopotentiometry (Fig. 6). The element Sm was selected to represent an RE element with variable valency. The shape of the curve obtained at the Mo electrode is remarkably different from the curves obtained at the $\mathrm{Al}$ electrode. The electrochemical window of the $\mathrm{Al}$ electrode is limited cathodically by $\mathrm{Li}(\mathrm{I})$ reduction forming a $\mathrm{Li}-\mathrm{Al}$ alloy, and anodically by the oxidation of the Al electrode, marked as $\mathrm{C}$ and $\mathrm{A}^{\prime}$, respectively. In this electroactive range, a group of signals $\mathrm{B} / \mathrm{B}^{\prime}$, were observed at a more positive potential than that at the Mo electrode. Since this potential value is more positive than the potential of Sm metal deposition, the cathodic peak is thought to be caused by the formation of an Al-Sm alloy. We can also see
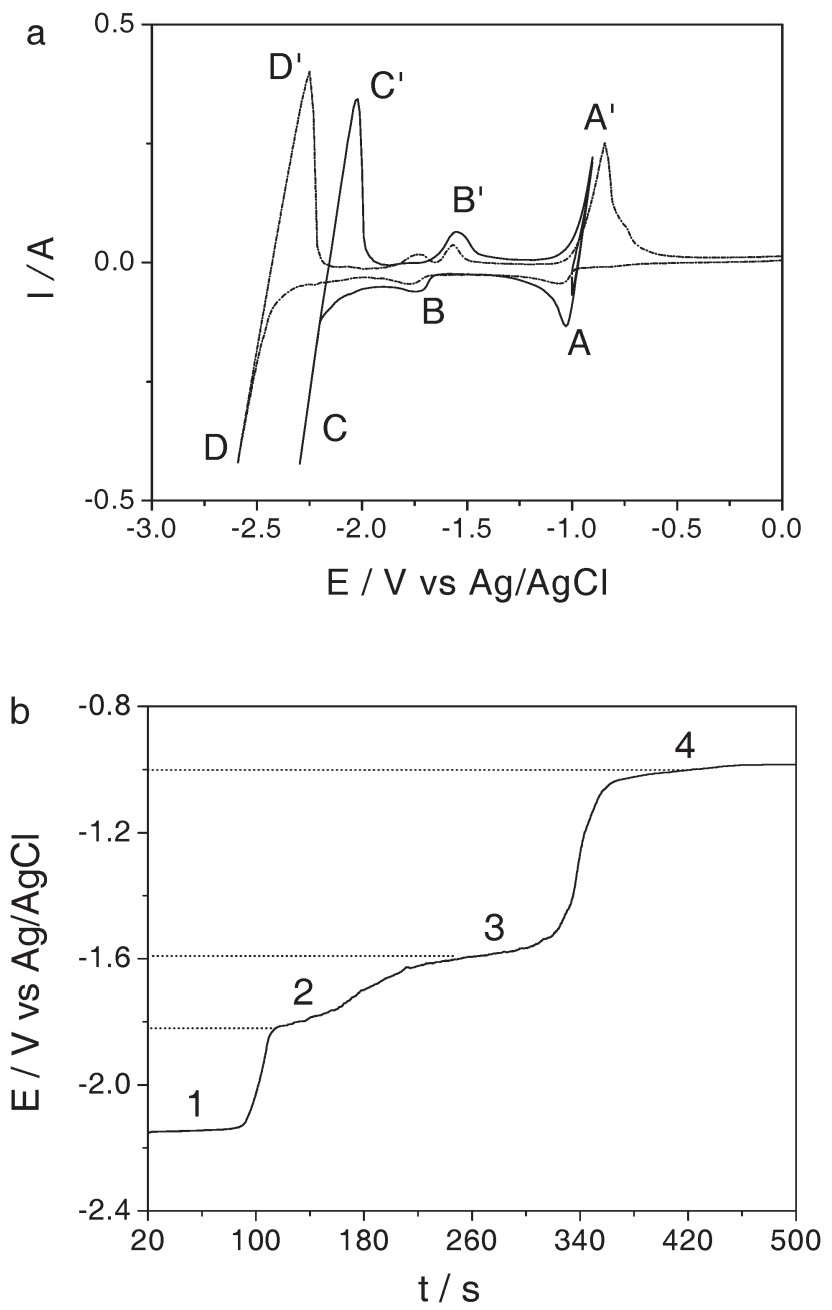

Fig. 6 (a) Cyclic voltammograms of the $\mathrm{LiCl}-\mathrm{KCl}-\mathrm{AlCl}_{3}(2 \mathrm{wt} \%)$ melts containing $1 \mathrm{wt} \%$ nano- $\mathrm{Sm}_{2} \mathrm{O}_{3}$ at $\mathrm{Mo}$ (dotted line) $\left(S=0.322 \mathrm{~cm}^{2}\right)$ and $\mathrm{Al}$ (solid line) $\left(S=0.598 \mathrm{~cm}^{2}\right)$ electrodes. Scan rate: $0.1 \mathrm{~V} \mathrm{~s}^{-1}$.(b) Opencircuit chronopotentiogram for $\mathrm{Al}$ electrode $\left(S=0.598 \mathrm{~cm}^{2}\right)$ after electrodepositing Li metal by galvanostatic electrolysis at $-200 \mathrm{~mA}$ for $5 \mathrm{~min}$ in the $\mathrm{LiCl}-\mathrm{KCl}$ melts containing $1 \mathrm{wt} \%$ nano- $\mathrm{Sm}_{2} \mathrm{O}_{3}$ at $480{ }^{\circ} \mathrm{C}$. that the reduction potential value of $\mathrm{Li}(\mathrm{I})$ is more positive at the $\mathrm{Al}$ electrode than that at the Mo electrode.

Cyclic voltammetry cannot be used to clearly identify the intermetallic compounds. So, open-circuit potentiometry was carried out to investigate the formation potential of Al-Sm alloys (Fig. 6b). The measurements were conducted as follows: after a short cathodic polarisation at a high cathodic over potential, the open-circuit potential of the electrode was measured versus time. Since the deposited Sm metal reacts with $\mathrm{Al}$ and diffuses into the bulk of the electrode, the electrode potential gradually shifts to more positive values. During this process, the evolution of the potential consists of successive plateaus, of increasing potential, each plateau typical of equilibrium in the solid state between two intermetallic compounds. The diffusion of Sm within the substrate explains the increase at potential of the cathode.

For $100 \mathrm{~s}$ in the beginning, the potential was kept at $-2.15 \mathrm{~V}$, assessed as the formation of Al-Li alloy. Potential plateaus, observed at (2) $-1.80 \mathrm{~V}$; (3) $-1.60 \mathrm{~V}$, are considered to correspond to the coexisting phase states of Al-Sm alloys. Finally, a potential plateau observed at $-1.00 \mathrm{~V}$ is the potential abandon of the $\mathrm{Al}$ electrode.

\subsection{Potentiostatic electrolysis and characterization of the deposits}

Based on the results obtained by CVs and chronopotentiogram, potentiostatic electrolysis was carried out in $\mathrm{LiCl}-\mathrm{KCl}$ melts containing $1 \mathrm{wt} \%$ nano- $\mathrm{Sm}_{2} \mathrm{O}_{3}$ and $2 \mathrm{wt} \% \mathrm{AlCl}_{3}$ with different concentrations on aluminum electrodes at $480{ }^{\circ} \mathrm{C}$. The structure, morphology, and energy dispersion analysis of deposit obtained by electrolysis are shown in Fig. 7. Fig. 7a presents the XRD patterns of Al-Sm alloys obtained by potentiostatic electrolysis from $\mathrm{LiCl}-$ $\mathrm{KCl}-\mathrm{AlCl}_{3}(2 \mathrm{wt} \%)-\mathrm{Sm}_{2} \mathrm{O}_{3}(1 \mathrm{wt} \%)$ at different potentials for $2 \mathrm{~h}$. The sample (i) obtained at $-1.7 \mathrm{~V}$ was identified as an $\mathrm{Al}_{3} \mathrm{Sm}$ and Al substrate. Thus, the alloy formed on the Al electrode is identified as the $\mathrm{Al}_{3} \mathrm{Sm}$ alloy. The sample (ii) was identified as a mixture of $\mathrm{Al}_{3} \mathrm{Sm}+\mathrm{Al}_{2} \mathrm{Sm}+\mathrm{KCl}$ at a more negative potential of $-2.0 \mathrm{~V}$. The morphology of the deposit obtained at a more negative potential $-2.2 \mathrm{~V}$ is shown in Fig. 7 b. Some white particles form on the Al substrate. To figure out the composition of the particles, EDS analysis was carried out. EDS of points A (Fig. 7c) and B (Fig. 7d) indicate that the Sm content in the alloys is relatively high. These Al-Sm-rich intermetallic compounds are mainly composed of $\mathrm{Al}$ and $\mathrm{Sm}$ elements with $\mathrm{Al}: \mathrm{Sm}$ atomic ratios of 1.80 and 2.51 , respectively, which are in good agreement with the stoichiometric ratio $(2: 1$ or $3: 1)$. This data suggests that $\mathrm{Al}_{2} \mathrm{Sm}$ and $\mathrm{Al}_{3} \mathrm{Sm}$ are formed during electrolysis.

\section{Conclusions}

The $\mathrm{RE}(\mathrm{RE}=\mathrm{Sm}, \mathrm{Eu}$, and $\mathrm{Yb})$ alloys with variable valent were prepared for the first time by electrolysis from the corresponding nano-rare earth oxides at $480{ }^{\circ} \mathrm{C}$ in $\mathrm{LiCl}-\mathrm{KCl}$ melts. Size, solubility and dispersion of the nano-particles in the $\mathrm{LiCl}-\mathrm{KCl}$ melts were examined. The bulk density ratios and solubility of nano- $\mathrm{Sm}_{2} \mathrm{O}_{3}$ / normal $\mathrm{Sm}_{2} \mathrm{O}_{3}$ are 0.77 and 16.98, respectively. Electrochemical behavior of $\mathrm{RE}_{2} \mathrm{O}_{3}$ on a molybdenum and $\mathrm{Al}$ electrode in $\mathrm{LiCl}-$ $\mathrm{KCl}$ melts containing $\mathrm{AlCl}_{3}$ at $480{ }^{\circ} \mathrm{C}$ was investigated by cyclic voltammetry, square wave voltammetry, and chronopotentiometry. The results of cyclic voltammetry indicates that the underpotential deposition of RE on pre-deposited aluminum leads to the 

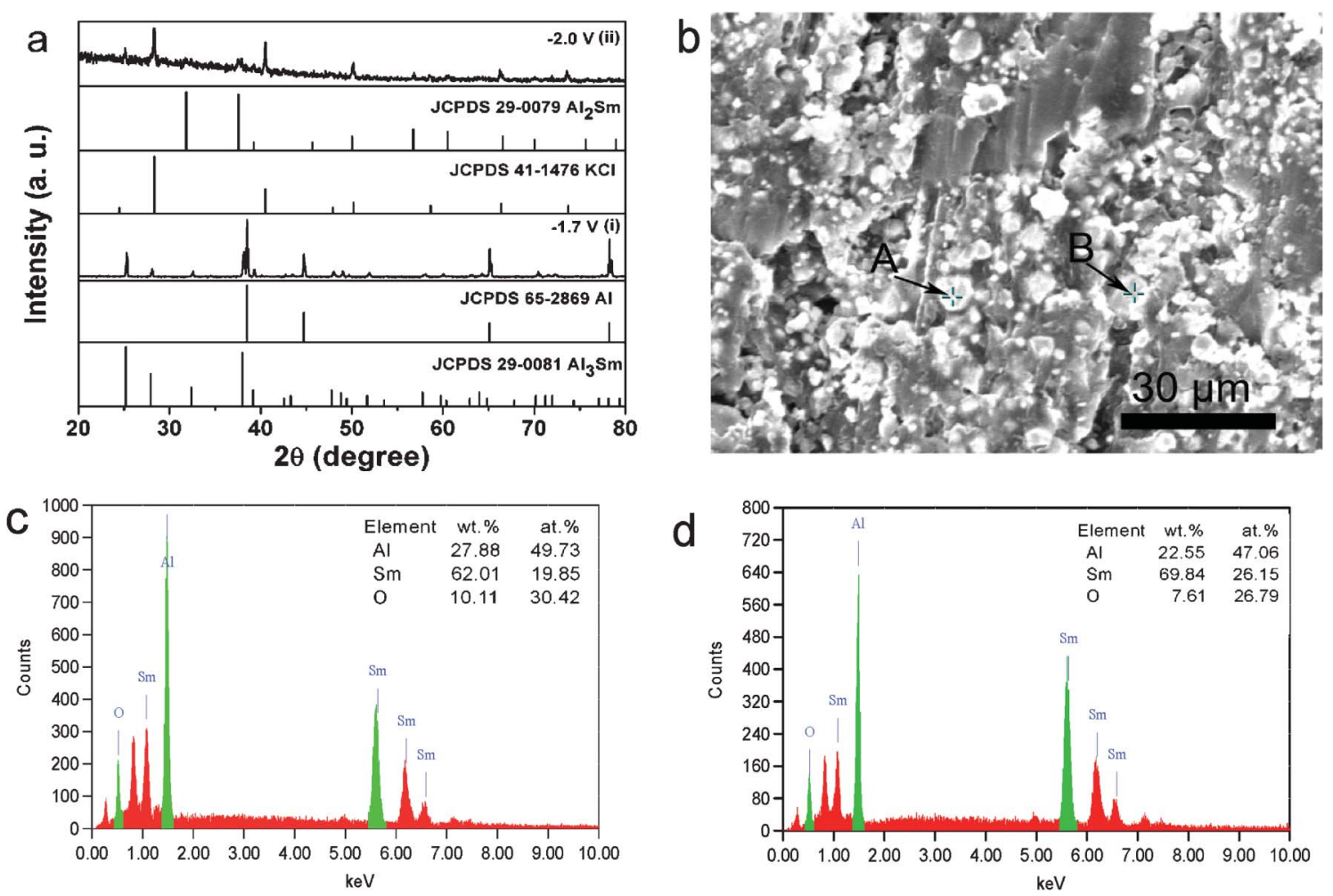

Fig. 7 (a) XRD patterns of Al-Sm alloys obtained at different potentials (i) -1.7 (ii) $-2.0 \mathrm{~V}$. (b) SEM and (c, d) EDS quantitative analysis of the deposit by potentiostatic electrolysis at $-2.2 \mathrm{~V}$ from the $\mathrm{LiCl}-\mathrm{KCl}-\mathrm{AlCl}_{3}(2 \mathrm{wt} \%)-\mathrm{Sm}_{2} \mathrm{O}_{3}(1 \mathrm{wt} \%)$ melts for $2 \mathrm{~h}$ at $480{ }^{\circ} \mathrm{C}$.

formation of $\mathrm{Al}-\mathrm{RE}(\mathrm{RE}=\mathrm{Sm}, \mathrm{Yb}$, and $\mathrm{Eu})$ alloy. The formation signals of Al-RE alloys also are detected in square wave voltammetry and open-circuit chronopotentiometry. The structure, morphology, and energy dispersion analysis of deposit obtained by potentiostatic electrolysis were analyzed, and the formation of A1-Sm alloys was confirmed.

\section{Acknowledgements}

The work was financially supported by the National 863 Project of the Ministry of Science and Technology of China (2009AA050702 and 2011AA03A409), the National Natural Science Foundation of China (50871033, 21103033, and 21101040), the Heilongjiang Postdoctoral Fund (LBH-Z10196 and LBH-Z10207), China Postdoctoral Science Foundation (20100480974) and Fundamental Research funds for the Central Universities. The authors are particularly grateful to Dr Tom Mann for kindly discussing various parts of the manuscript.

\section{References}

1 T. Iida, T. Nohira and Y. Ito, Electrochim. Acta, 2001, 46, 2537-2544. 2 T. Iida, T. Nohira and Y. Ito, Electrochim. Acta, 2003, 48, $1531-1536$.

3 T. Iida, T. Nohira and Y. Ito, Electrochim. Acta, 2003, 48, 2517-2521.

4 M. R. Bermejo, F. de la Rosa, E. Barrado and Y. Castrillejo, J. Electroanal. Chem., 2007, 603, 81-95.

5 Y. Castrillejo, P. Fernández, M. R. Bermejo, E. Barrado and A. M. Martínez, Electrochim. Acta, 2009, 54, 6212-6222.

6 S. A. Kuznetsov and M. Gaune-Escard, Electrochim. Acta, 2001, 46, $1101-1111$.
7 V. Smolenski, A. Novoselova, A. Osipenko, C. Caravacac and G. Córdoba, Electrochim. Acta, 2008, 54, 382-387.

8 G. Z. Chen, D. J. Fray and T. W. Farthing, Nature, 2000, 407, 361-364.

9 D. H. Wang, G. H. Qiu, X. B. Jin, X. H. Hu and G. Z. Chen, Angew. Chem., Int. Ed., 2006, 45, 2384-2388.

10 T. Nohira, K. Yasuda and Y. Ito, Nat. Mater., 2003, 2, 397-401.

11 X. B. Jin, P. Gao, D. H. Wang, X. H. Hu and G. Z. Chen, Angew. Chem., 2004, 751-754Angew. Chem. Int. Ed. 2004, 43, 733-736.

12 M. Yu, J. Lin, Z. Wang, J. Fu, S. Wang, H. J. Zhang and Y. C. Han, Chem. Mater., 2002, 14, 2224-2231.

13 Y. D. Yan, M. L. Zhang, Y. Xue, W. Han, X. Y. Jing, L. Y. He and Y. Yuan, Phys. Chem. Chem. Phys., 2009, 11, 6148-6155.

14 Y. D. Yan, M. L. Zhang, Y. Xue, W. Han, D. X. Cao and S. Q. Wei, Electrochim. Acta, 2009, 54, 3387-3393.

15 F. Ma and K. W. Xu, Surf. Interface Anal., 2007, 39, 611-614.

16 S. L. Lai, J. Y. Guo, V. Petrova, G. Ramanath and L. H. Allen, Phys. Rev. Lett., 1996, 77, 99-102.

17 K. K. Nanda, F. E. Kruis and H. Fissan, Phys. Rev. Lett., 2002, 89, 256103-1-256103-4

18 M. Hirasawa, T. Orii and T. Seto, Appl. Phys. Lett., 2006, 88, 093119-1-093119-3.

19 J. Yang, Z. W. Quan, D. Y. Kong, X. M. Liu and J. Lin, Cryst. Growth Des., 2007, 7, 730-735.

20 H. Wang, M. Yu, C. K. Lin, X. M.Liu and J. Lin, J. Phys. Chem. C, 2007, 111, 11223-11230

21 Z. Y. Hou, H. Z. Lian, M. L. Zhang, L. L. Wang, M. F. Lv, C. M. Zhang and J. Lin, J. Electrochem. Soc., 2009, 156, J209-J214.

22 G. Cordoba and C. Caravaca, J. Electroanal. Chem., 2004, 572, $145-151$.

23 J. A. Plambeck (ed.:A. J. Bard), Encyclopedia of Chemistry of the Elements, vol. 10, Marcel Dekker, New York, 1976.

24 A. V. Bychkov and O. V. Skiba, Pyrochemical Separations, Workshop Proceeding OECD/NEA, Avignon, France, 2000.

25 T. B. Massalski, J. L. Murray, L. H. Benett and H. Baker, Binary alloy Phase Diagrams, American Society for Metals, 1990. 